The effect of Military expenditure on economic growth in the World

Dr/ Abdalla Sayed Mossalem Ahmed Elshafei

\title{
The effect of Military expenditure on economic growth in the World
}

\section{Abdalla Sayed Mossalem Ahmed Elshafei}

Economic lecturer in higher institute for administration, financial science and information system.

\section{Abstract:}

- The study measures the effect of military expenditure on economic growth, Econometric approaches analyzed the relationship between GDP growth and Military expenditure in the world as one country, Empirical studies have been done using regression analysis equation and cointegration analysis and causality test to justify the relationship and causality of the variables, the results of regression indicate a positive relationship between the two variables in this study.

\section{Purpose:}

- The purpose of this paper measure relationship between world military expenditure and economic growth in the world during the period of 1960-2018.

\section{Design/methodology:}

- The methodology consisted of 3 stages:

1- Assessment world military expenditure and economic growth indicators over five decades use statistics analysis.

2- Regression analysis to identify the relationships between world military expenditures (WME) and economic growth. 
The effect of Military expenditure on economic growth in the World

Dr/ Abdalla Sayed Mossalem Ahmed Elshafei

3- Estimation of causality between WME and economic growth, modeling the relationship by the Granger causality testing.

- Keywords: the world, Economic growth, Granger causality, world military expenditure.

\section{1- Introduction:}

- The relationship between military spending and economic growth has come a great controversy, Between the presence of positive effects of military spending on economic growth, represented in increasing the infrastructure within the state, introducing modern state technology in the case of military industrialization ${ }^{1}$, increasing human development through training and education in the military sector, and increasing the military capacity, which achieves internal and external security, and increases Both domestic and foreign investment opportunities $^{2}$, As for the negative effects of military spending on economic growth, exemplified by competition from private investment when constant domestic savings ${ }^{3}$.

- In the other hand, military expenditure Waste economic resource, which can use in development and growth, program of the national united indicate ${ }^{4}$ to transfer little part of the resource which use in military expenditure ( 80 billion dollars annual) it's enough to achieve goals of world growth for developing countries. 
The effect of Military expenditure on economic growth in the World

Dr/ Abdalla Sayed Mossalem Ahmed Elshafei

\section{2- Empirical evidence and research methodology}

- Daniel Landau ${ }^{5}$ military spending increase for the full sample of 71 countries, the growth rate at first increases and then decreases use reviewing trends in military spending across regions and over time, analyzing the impact of military expenditures on economic growth. Biswas ${ }^{6}$ use Feder's 19831986 models developed, to measure the relationship between military spending and economic growth, many studies used Feder's model developed to measure the relationship between military spending and economic growth (Paul Dunne, 2001). Deger $^{7}$, explained resources diverted to non-military activities and military activities which have negatively effected in economic activities, except when total demand is less than total supply, military expenditures will have positively affected the growth process (deger, 1995). Mintz ${ }^{8}$ indicates to the absence of a significant relationship between military expenditure and economic growth in the short term (Mintz, 1994). Wilkins ${ }^{9}$ found that the average military expenditure fell from $4.78 \%$ in 1988 to $2.95 \%$ in 2001, as a result of the end of the Cold War Paul Dunne \& Ron Smith, 2001). Halicioglu ${ }^{10}$ indicate to a positive relationship between military expenditure and total production in Turkey in the long term (Ferda Halicioglu, 2004). Shahbaz ${ }^{11}$ studies the impact of military spending on economic growth using a Keynesian model of India from 1971 to 2010. Shih-Ying ${ }^{12}$ 
The effect of Military expenditure on economic growth in the World

Dr/ Abdalla Sayed Mossalem Ahmed Elshafei

use a large sample of 182 countries over a long period of time, Granger causality test to examine the relationship between government spending and economic growth. Show that government expenditure and economic growth Granger cause each other (Shih-Ying, 2010). Shahbaz found positive impact of military spending on economic growth, there is a negative impact on economic growth if military spending increases for a Specific level, this study also showed a twoway causal relationship between military expenditure and economic growth (Shabazz \& Tiwari, 2011). Dr.Howyda Abed Aazim Zidan $^{13}$ found that there is a causal relationship in one direction, between government spending and military spending and no impact of military spending on economic growth in the long term (Dr.Howyda Abed Aazim Zidan, 2015). Abdalla ${ }^{14}$ (authors), the results of the estimation of the regression model used for the study: Indicates a negative correlation between the per capita GDP and military expenditure in Nigeria. Moreover, a positive relationship between non-military spending and average GDP per capita. In addition, a positive relationship between non-military spending and average GDP per capita, A negative relationship between the average interest rate and average per capita GDP (Abdalla, 2018). Mohammad Hasan Raju and Zobayer Ahmed ${ }^{15}$ the study got a positive long run relationship and long-run causality from military to GDP 
The effect of Military expenditure on economic growth in the World

Dr/ Abdalla Sayed Mossalem Ahmed Elshafei

growth, but no short run relationship for all the three countries (India Pakistan and China) (Mohammad Hasan Raju and Zobayer Ahmed, 2019).

\begin{tabular}{|l|l|}
\hline \multicolumn{1}{|c|}{ Authors } & \multicolumn{1}{c|}{ The methods applied } \\
\hline Biswas and Ram (1986) & Linear regression analysis equation \\
\hline Deger and Sen (1995) & Linear regression analysis equation \\
\hline Mintz and Stevenson (1995) & Cross Section Analyses \\
\hline Wilkins (2004) & Cross Section Analyses \\
\hline Halicioglu(2004) & Cross Section Analyses \\
\hline Shih-Ying(2010) & Causality Analysis \\
\hline Tiwari and Shahbaz (2011) & Multiple regression analysis equation \\
\hline Dr.Howyda Abd Aazim Zidan (2015) & Causality Analysis \\
\hline Abdalla(2018) & Multiple regression analysis equation \\
\hline Mohammad Hasan Raju(2019) & Causality Analysis \\
\hline Source: Summary made by authors & \\
\hline
\end{tabular}

3- Assessment world military expenditure and economic growth indicators over five decades use statistics analysis World military expenditure amounted to 8353.78 billion dollar (table1), and $5.7 \%$ of the world GDP (table2) in period 1960-1969, World military expenditure increased to 15118.56 billion dollar (table1), and decreased to 2.3 percent of the world GDP (table2) in period 2011-2019. 
The effect of Military expenditure on economic growth in the World

Dr/ Abdalla Sayed Mossalem Ahmed Elshafei

Table1

World Military expenditure (1960-2019)

Billion (Constant 2010 US\$)

\begin{tabular}{|l|l|l|l|l|l|l|}
\hline Period & $1969-$ & $1970-$ & $1980-$ & $1990-$ & $2000-$ & $2011-$ \\
& 1970 & 1979 & 1989 & 1999 & 2010 & 2019 \\
\hline WME & 8353.78 & 9046.87 & 12079.88 & 10751.91 & 12108.85 & 15118.56 \\
\hline
\end{tabular}

Source: Authors' calculations based on World Bank data.

- We found world military expenditure increased in all period started at 1969 to 2019 (table1), except period 1990-1999 decreased about the previous period because the end of cold war and fall of the Soviet Union (table1,2)

\section{Table2}

World Military expenditure (1960-2019)

\section{(\% of GDP)}

\begin{tabular}{|l|c|c|c|c|c|c|}
\hline Period & $\begin{array}{l}1969- \\
1970\end{array}$ & $\begin{array}{l}1970- \\
1979\end{array}$ & $\begin{array}{l}1980- \\
1989\end{array}$ & $\begin{array}{l}1990- \\
1999\end{array}$ & $\begin{array}{l}2000- \\
2010\end{array}$ & $\begin{array}{l}2011- \\
2019\end{array}$ \\
\hline WME & 5.7 & 3.9 & 3.8 & 2.6 & 2.3 & 2.3 \\
\hline
\end{tabular}

Source: Source: Authors' calculations based on Table 1 and 2 data.

\section{Table3}

World Military expenditure rate (1960-2019)

\%
\begin{tabular}{|c|c|c|c|c|c|c|}
\hline Period & $1969-$ & $1970-$ & $1980-$ & $1990-$ & $2000-$ & $2011-$ \\
& 1970 & 1979 & 1989 & 1999 & 2010 & 2019 \\
\hline WME & 0 & 0.24 & 0.13 & -0.11 & 0.34 & 0.083 \\
\hline
\end{tabular}

Source: Authors' calculations based on Table1 data.

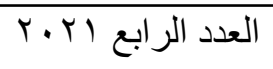

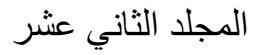


The effect of Military expenditure on economic growth in the World

Dr/ Abdalla Sayed Mossalem Ahmed Elshafei

- World economic growth amounted to 145799.09 billion dollars (table3) in the period 1960-1969, and increased to 665373.85 billion dollars (table3).

- We found economic growth, increased during the period 1970-2019 except period 1980-1989 decreased about the previous period because (table4,5)

\section{Table4}

World economic growth (1960-2019)

\section{Billion (Constant 2010 US\$)}

\begin{tabular}{|l|c|c|c|c|c|c|}
\hline Period & $1969-1970$ & $1970-1979$ & $1980-1989$ & $1990-1999$ & $2000-2010$ & $2011-2019$ \\
\hline GE & 145799.09 & 231948.85 & 315027.9 & 421013.71 & 518366.33 & 665373.85 \\
& & & & & & \\
\hline
\end{tabular}

Source: Authors' calculations based on World Bank data.

Table 5

World economic growth rate (1960-2019)

\%
\begin{tabular}{|l|c|c|c|c|c|c|}
\hline Period & $\begin{array}{c}1969- \\
1970\end{array}$ & $\begin{array}{c}1970- \\
1979\end{array}$ & $\begin{array}{c}1980- \\
1989\end{array}$ & $\begin{array}{c}1990- \\
1999\end{array}$ & $\begin{array}{c}2000- \\
2010\end{array}$ & $\begin{array}{c}2011- \\
2019\end{array}$ \\
\hline GE & 0 & 0.28 & 0.23 & 0.34 & 0.36 & 0.59 \\
\hline
\end{tabular}

Source: Authors' calculations based on World Bank Table 2 data 
The effect of Military expenditure on economic growth in the World

Dr/ Abdalla Sayed Mossalem Ahmed Elshafei

- In the graph 1 we see the world economic growth rate curve similar the military expenditure rate curve, it is indicated to the relationship between world economic growth and world military expenditure in during period from 1970 to 2019.

- During the period 1970-1979 increased in the two curves, during period 1980-1989 decreased in the two curves, the big decreased during period 1990-1999 in the two curves, and increased in two curves during period 2000-2010, and decreased in the last period in this study (2011-2019), so necessary to make regression analysis and causality test between world economic growth and world military expenditure.

\section{Graph 1}

World economic growth rate and World Military expenditure growth rate

(1960-2019)

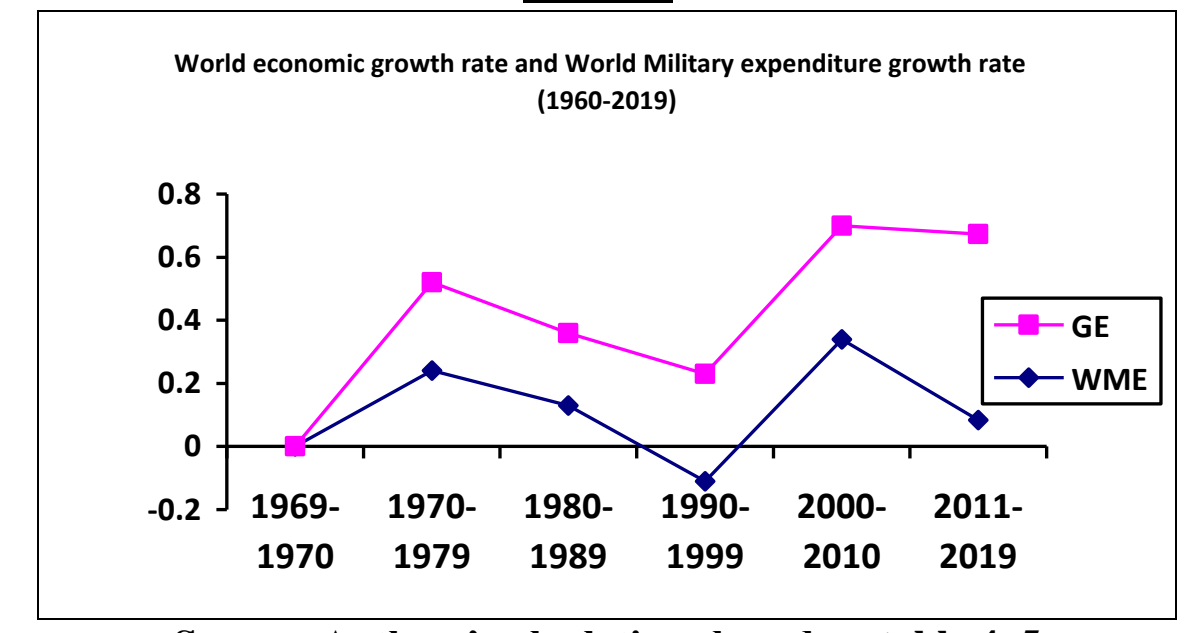

Source: Authors' calculations based on table 4, 5 
The effect of Military expenditure on economic growth in the World

Dr/ Abdalla Sayed Mossalem Ahmed Elshafei

4- Regression analysis to identify the relationships between world military expenditures (WME) and economic growth .

\begin{tabular}{|l|l|c|l|}
\hline Variable & \multicolumn{1}{|c|}{ definition } & source & Variable type \\
\hline WME & world military expenditures & World bank & independent \\
\hline GE & world economic growth & World bank & dependent \\
\hline
\end{tabular}

\section{Variables of study 1960-2019}

\section{Unit Root Test}

- Time-series of variable GE, it was not stable at the level (t-statistic -5.8 Prop 1), and stable at the level 1 (t-statistic 4,4 Prop 0,0007) it is a good indicator to complete a form estimate.

- Time-series of variable WME, it was stable at the level tstatistic -0,34 Prop 0.89, and stable at the level 1 ( $t$ statistic -0,34 Prop 0,89), it is a good indicator to complete a form estimate.

Augmented Dickey-Fuller

\begin{tabular}{|c|c|c|c|c|c|c|}
\hline \multirow{2}{*}{ Variable } & \multicolumn{6}{|c|}{ ADF } \\
\cline { 2 - 7 } & \multicolumn{2}{|c|}{ level } & \multicolumn{2}{c|}{ 1st difference } & \multicolumn{2}{|c|}{ 2nd difference } \\
\cline { 2 - 7 } & $\begin{array}{c}\text { T- } \\
\text { statistic }\end{array}$ & Prob & T-statistic & Prob & T-statistic & Prob \\
\hline GE & 5.8 & 1 & 4.4 & 0.0007 & & \\
\hline WME & -0.34 & 0.89 & -4.7 & 0.0003 & & \\
\hline
\end{tabular}

EVie

Ws 9

- The results of the Johansson-Integration test indicates rejecting the initial hypothesis, that there was no common 
The effect of Military expenditure on economic growth in the World

Dr/ Abdalla Sayed Mossalem Ahmed Elshafei

integration between the time-series of the study variables, it is a good indicator to complete a form estimate.

Johansson test

\begin{tabular}{|c|c|c|}
\hline Likelihood Ratio & $\begin{array}{c}\text { Critical value } \\
\text { Sig level }=\cdot \text {. }^{\text {o }}\end{array}$ & Hypothesized No. of CE(s) \\
\hline 20.3 & 15.49 & None \\
\hline 5.9 & 3.8 & At most 1 \\
\hline
\end{tabular}

EVie

ws 9

- The results of regression indicate a positive relationship between two variables that $\mathrm{R}$-squared $=0.83$ means that independent variables show $83 \%$ of the change in the dependent variable.

$$
\begin{gathered}
\mathrm{GE}=-3.32+62.74 \times \mathrm{WME} \\
\text { Result }
\end{gathered}
$$

\begin{tabular}{|c|c|c|c|c|}
\hline Variable & coefficient & S.E & T -statistics & P-value \\
\hline c & -3.2 & 4.44 & -7.5 & 0.0000 \\
\hline WME & 62.7 & 3.69 & 16.9 & 0.0000 \\
\hline R-squared $=0.83$, Adj R-squared $=0.83, \mathrm{DW}=0.137$ \\
\hline
\end{tabular}

EVie

ws 9

5- Estimation of causality between WME and economic growth modeling the relationship by the Granger causality testing. 
The effect of Military expenditure on economic growth in the World

Dr/ Abdalla Sayed Mossalem Ahmed Elshafei

Granger test indicates to long term relationship between WME and GE in one side from GE to WME.

\begin{tabular}{|c|c|c|c|c|}
\hline Granger test & $\begin{array}{c}\text { Observations } \\
\text { /lags }\end{array}$ & F-Statistic & Prob. & Test results \\
\hline $\begin{array}{c}\text { WME does not } \\
\text { Granger Cause GE }\end{array}$ & 57 & 0.01863 & 0.9815 & Rejected \\
\cline { 1 - 3 } $\begin{array}{c}\text { GE does not Granger } \\
\text { Cause WME }\end{array}$ & & 3.47325 & 0.0384 & Accepted \\
\cline { 3 - 5 } & & & \\
\hline
\end{tabular}

EVie

WS 9

\section{Conclusion:}

The main objective of this research is to examine the relationship between world military expenditure and world economic growth. Recent studies apply a lot of test, for ex, Granger causality test to examine whether military expenditure causes economic growth or economic growth causes military expenditure. all previous studies examines relationship between economic growth and military expenditure on countries level, but in this study measure relationship consider of all worlds as one country to show effect at the level of the world, so we fear about the country's problem which effect on this relationship, which appear if study one country or a group of countries. the results of regression indicate a positive relationship between the two variables in this study, the important reason for this result, we find a few countries in the world (ex: United States - 
The effect of Military expenditure on economic growth in the World

Dr/ Abdalla Sayed Mossalem Ahmed Elshafei

Russia - china - France - Germany) control in $75 \%$ military industry united states, Russia more than $57 \%$ in military industry, which also the biggest countries in economic growth compare with other world countries, which import military machines from this countries.

so we find appositive relationship, although the military expenditure consider a big problem to all the world except this countries, because the imports increase more than exports which cause weakness in economic and increase poverty in the world, the only benefit from military expenditure in the world for this countries United States - Russia - china - France - Germany, which control in industry and growth in the world.

In terms of Granger causality indicate to economic growth cause the world military expenditure, when economic increase in a big countries in the world, which help this countries to increase the ability in its military industry, because it think its ability in military industry will be more strong in the world, and it try to buy old version from its product in machines military to develop countries which It controls dominance and power, which emphasize a correct pervious analysis. 
The effect of Military expenditure on economic growth in the World

Dr/ Abdalla Sayed Mossalem Ahmed Elshafei

\section{References :}

1 Deger Saadet, Ron Smith, Military Expenditure and Growth in Less Developed Countries (New York: Vol. 27, No. 2, 1983). P339

2 Brasoveanu, Laura Obreja, The Impact Of Defense Expenditure On Economic Growth, Journal Of Economic Forecasting (Romanian: Volume 13, No. 4, 2010) P160

${ }^{3}$ Khilji Nasir, Akhtar Mahmoud, Military Expenditures And Economic Growth In Pakistan, The Pakistan Development Review (Pakistan: Part II, 1997)

${ }^{4}$ Deger Saadet. Ron Smith, Military Expenditure and Growth in Less Developed Countries, the Journal of Conflict Resolution (New York: The Journal Of Conflict Resolution, Vol. 27, No.2, 1983). P339

5 Daniel Landau, The Economic Impact of Military Expenditures (Washington DC: world bank, Policy Research Department, wps1138, 1993)

${ }^{6}$ Paul Dunne, Ron Smith, Theoretical And Econometric Issues In Analyzing The Military Expenditure-Growth Nexus (London: University Business School, Centre For Applied Research In Economics, 2001.

${ }^{7}$ Paul Dunne, Ron Smith, Theoretical And Econometric Issues In Analyzing The Military Expenditure-Growth Nexus, Op.Cit P5

8 Paul Dunne, Ron Smith, Theoretical And Econometric Issues In Analyzing The Military Expenditure-Growth Nexus, Op.Cit P5

${ }^{9}$ Paul Dunne, Ron Smith, Theoretical and Econometric Issues in Analyzing the Military Expenditure-Growth Nexus, Op.Cit. P5

${ }^{10}$ Ferda Halicioglu, Defense Spending and Economic Growth in Turkey: An Empirical Application of New Macroeconomic Theory (London: Middle East Econ. Fin., VOL.2, NO.3, 2004). 
The effect of Military expenditure on economic growth in the World Dr/ Abdalla Sayed Mossalem Ahmed Elshafei

11 Shahbaz, Tiwari, Does Defense Spending Stimulate Economic Growth In India? A Revisit (London: Defense and Peace Economics, Vol. 24, No. 4, 371-395, 2013)

12 Shih-Ying Wu, Jenn-Hong Tang, and Eric S. Lin, The impact of government expenditure on economic growth: How sensitive to the level of development? (Journal of Policy Modeling, 32, 2010)

13 Dr. Howyda Abd Aazim Zidan, (2015). "Military Spending and Economic Growth A Case Study Algeria Using Causality Analysis", Egyptian Society of Political Economy and Statistics And Legislation, 1-15

14 Abdalla sayed Messalam, (2018). The Impact of Military Spending on Economic Growth in Nigeria since 1990, Journal of Economics and Sustainable Development, Vol.9, No.22, 2018, 115-123.

15 Mohammad Hasan Raju and Zobayer Ahmed, (2019). Effect of military expenditure on economic growth: evidences from India Pakistan and China using cointegration and causality analysis (Asian Journal of German and European Studies, (2019) 4:3). 